\section{Crisphead Lettuce Breeding Lines with Resistance to Corky Root and Lettuce Mosaic Virus}

\author{
Beiquan Mou', Ryan J. Hayes, and Edward J. Ryder \\ U.S. Department of Agriculture, Agricultural Research Service, 1636 East \\ Alisal Street, Salinas, CA 93905
}

Additional index words. Rhizomonas suberifaciens, Sphingomonas suberifaciens, disease resistance, Lactuca sativa, germplasm

Corky root of lettuce (Lactuca sativa L.) has been observed in major lettuce-producing areas of the world, including North America, Western Europe, Australia, and New Zealand. Roots of infected plants develop yellow to brown lesions that later become longitudinal corky ridges. In severely infested fields in California and Florida, yield losses from reduced head size can reach $30 \%$ to $70 \%$. The pathogen most commonly isolated from diseased roots is the bacterium Sphingomonas suberifaciens (Yabuuchi et al., 1999), formerly Rhizomonas suberifaciens, although several other bacterial species have been isolated (van Bruggen, 1997). The incidence of corky root may be reduced by soil fumigation (O'Brien and van Bruggen, 1990) and by using lettuce transplants instead of direct seeding (van Bruggen and Rubatzky, 1992), but these practices may not be economically feasible for the Salinas Valley, the major lettuce production area in California (Patterson et al., 1986). The use of cultivars resistant to S. suberifaciens has been and should continue to be an important management strategy for corky root. The resistance to corky root is conferred by a recessive allele (cor) at a single locus (Brown and Michelmore, 1988), which has been deployed in most resistant lettuce cultivars.

Lettuce mosaic virus (LMV) causes serious disease problems in the production of lettuce worldwide. Plants susceptible to LMV exhibit systemic symptoms of vein clearing, mottling, leaf recurving, leaf margin frilling, distortion, stunting, and occasional necrosis. LMV is primarily transmitted by the green peach aphid (Myzus persicae Sulz.) and can cause losses of up to $100 \%$ (Ryder, 2002). In California, the disease is generally controlled by the use of virus-free seeds in a seed certification program. In

\footnotetext{
Received for publication 20 Nov. 2006. Accepted for publication $10 \mathrm{Feb} .2007$.

This research was supported in part by grants from the California Lettuce Research Board.

We thank JoAnn Tanaka, David Milligan, and Sharon Benzen for technical assistance and Gary Vallad and Yaojin Peng for critical review and discussion of the manuscript.

${ }^{1}$ To whom reprint requests should be addressed; e-mailbmou@pw.ars.usda.gov
}

Europe, South America, and other lettucegrowing areas, lettuce mosaic is controlled through the use of resistant cultivars (Zerbini and Gilbertson, 1997). Two recessive resistant alleles at a single locus, $m o-l^{g}\left(m^{1} l^{1}\right)$ and $m o-l^{e}\left(\mathrm{~mol}^{2}\right)$, are incorporated in resistant cultivars in Europe and in the United States, respectively (Dinant and Lot, 1992; Ryder, 1970) and have recently been cloned and sequenced (Nicaise et al., 2003).

Although a crisphead cultivar with resistance to both corky root and lettuce mosaic is commercially available, it is protected by a utility patent (Sarreal, 1997), which greatly restricts breeding research. Although the Plant Variety Protection Act in the United States allows the use of a protected cultivar for breeding, a patent prohibits the use of registered material for breeding without assignee permission. There is a need for public germplasm that will facilitate the research and development of new cultivars and germplasm. In this article, we describe seven breeding lines with combined resistance to the two diseases and adaptation to the major lettuce production areas of the central coast of California.

\section{Origin}

The breeding lines were derived from crosses between cultivars 'Salinas 88 ' that has $m o-l^{e}\left(m o l^{2}\right)$ alleles (Ryder, 1991) and 'Glacier' and 'Misty Day' that have cor alleles (Ryder and Waycott, 1994). The $F_{1}$ plants were backcrossed to 'Salinas 88' once, and $\mathrm{BC}_{1} \mathrm{~F}_{1}$ and $\mathrm{BC}_{1} \mathrm{~F}_{2}$ generations were screened for resistance to $\mathrm{LMV}$ in a greenhouse. $\mathrm{BC}_{1} \mathrm{~F}_{3}$ to $\mathrm{BC}_{1} \mathrm{~F}_{6}$ progenies were grown in a field with a history of corky root disease and were selected for resistance to corky root and desired head characters. $\mathrm{BC}_{1} \mathrm{~F}_{6}$ breeding lines 04-0344, 04-0350, 040353, 04-0363, 04-0368, and 04-0375 are from the original cross to 'Glacier', whereas 04-0379 came from the cross to 'Misty Day'.

\section{Description}

The breeding lines have dull, medium dark green outer leaves similar to 'Salinas 88 ' and related cultivars. Green color extending close to the core is visible on a partially trimmed head. The interior is creamy yellow.
Leaf margins are incised, indented, and mildly undulated. The leaf surface is slightly crinkled or blistered. Outer leaves are broader than long. Heads are well rounded, partially covered, and firm at maturity. The butt is flat, and ribs are flat but become more pointed toward the base. Bases of outer and interior leaves overlap well. The texture is relatively soft and flexible, and inside leaves are crispy. Seeds are black.

Disease resistance. The breeding lines, along with commercial cultivars, were planted in trials at the Spence Farm of the Agricultural Research Service of the USDA, Salinas, Calif., on 18 May 2004 and 14 June 2005 and in commercial production fields at Triangle Farm, Salinas, Calif., on 10 July 2004 and at Huntington Farms, Soledad, Calif., on 4 May 2005. Cultivar 'Salinas', susceptible to corky root, was included in all trials as a control. The experimental design was a randomized complete block with two replications. Each plot was $15 \mathrm{~m}$ long and consisted of two rows of plants at the commercial spacing of $30 \mathrm{~cm}$ between plants and $35 \mathrm{~cm}$ between rows on a 1-m-wide bed. Standard production practices were followed in these trials. At harvest maturity, the roots of six randomly selected plants from each plot were rated using Brown and Michelmore's (1988) scale of 0-9 (0, no disease symptom; 9 , plant died from the disease). The corky root ratings of the breeding lines were not significantly different from the cultivars with the cor gene, 'Bronco', 'Cannery Row', 'Glacier', 'Premiere', 'Sharp Shooter', and 'Sniper', but were significantly lower than the susceptible cultivars 'Salinas' and 'Silverado' (Table 1).

The breeding lines were tested for their resistance to lettuce mosaic following the method described by Ryder (2002). Fifteen randomly selected seeds from each line, resistant control 'Salinas 88', and susceptible controls 'Glacier' and 'Misty Day' were sown in plastic pots $(10 \times 10 \times 10-\mathrm{cm})$ containing a mixture of 2 sand: 1 soil (by volume) and were germinated and grown in a greenhouse. Plants were thinned to 12 per pot and were inoculated at the three- to four-leaf stage. The virus used was originally collected from a single plant in a lettuce field in the Salinas Valley in 1958. It has been maintained at the U.S. Dept. of Agriculture facility in Salinas by plant-to-plant transfer without any apparent loss in virulence. The vector was the green peach aphid, cultured on a long white radish, transferred to LMV-infected lettuce plants and then to healthy seedlings. Symptoms were evaluated $22 \mathrm{~d}$ after inoculation. The tests were carried out twice. No plants from the seven breeding lines or resistant 'Salinas 88 ' exhibited symptoms of lettuce mosaic, whereas all plants of the susceptible 'Glacier' and 'Misty Day' developed typical disease symptoms (data not shown).

From field observations, these breeding lines had moderate resistance to downy mildew (Bremia lactucae Regel) similar to 'Salinas' that has $D m 5 / 8, D m 7$, and $D m 13$ 
Table 1. Means of corky root rating, head weight, harvest percentage, and tipburn for lettuce breeding lines and cultivars grown in trials in 2004 at Triangle Farm, in 2004 and 2005 at Spence Farm, Salinas, Calif., and in 2005 at Huntington Farm, Soledad, Calif.

\begin{tabular}{|c|c|c|c|c|c|c|c|c|c|c|c|}
\hline \multirow[b]{2}{*}{ Genotype } & \multicolumn{2}{|c|}{2004 Spence Farm } & \multicolumn{3}{|c|}{2004 Triangle Farm } & \multicolumn{3}{|c|}{2005 Spence Farm } & \multicolumn{3}{|c|}{2005 Huntington Farm } \\
\hline & $\begin{array}{c}\text { Corky } \\
\text { root }^{\mathrm{z}}\end{array}$ & $\begin{array}{l}\text { Head } \\
\text { wt }(\mathrm{g})\end{array}$ & $\begin{array}{c}\text { Corky } \\
\text { root }\end{array}$ & $\begin{array}{l}\text { Head } \\
\text { wt }(\mathrm{g})\end{array}$ & Harvest \% & $\begin{array}{c}\text { Corky } \\
\text { root }\end{array}$ & $\begin{array}{l}\text { Head } \\
\text { wt }(\mathrm{g})\end{array}$ & Tipburn/head ${ }^{y}$ & $\begin{array}{c}\text { Corky } \\
\text { root }\end{array}$ & $\begin{array}{l}\text { Head } \\
\text { wt }(\mathrm{g})\end{array}$ & Harvest $\%$ \\
\hline $04-0344$ & 4.0 & 1078.8 & 5.9 & 910.4 & 94.5 & 5.8 & 969.0 & 0.8 & 5.9 & 933.2 & 94.2 \\
\hline 04-0350 & 5.5 & 927.6 & 5.9 & 784.4 & 93.2 & 5.6 & 1071.8 & 0.6 & 6.0 & 879.0 & 90.9 \\
\hline 04-0353 & 5.5 & 948.3 & 5.9 & 839.3 & 96.3 & 5.8 & 981.4 & 1.3 & 5.6 & 794.4 & 91.2 \\
\hline 04-0363 & 4.8 & 887.6 & 6.1 & 822.3 & 84.8 & 5.8 & 901.0 & 0.8 & 6.0 & 767.0 & 78.1 \\
\hline 04-0368 & 5.5 & 940.5 & 5.9 & 825.3 & 83.4 & 6.0 & 861.3 & 1.1 & 6.2 & 802.0 & 87.5 \\
\hline 04-0375 & 5.0 & 851.5 & 5.8 & 830.8 & 91.0 & 6.0 & 1028.2 & 0.6 & 5.9 & 816.3 & 90.4 \\
\hline 04-0379 & 5.3 & 1018.4 & 5.8 & 883.1 & 90.3 & 5.9 & 983.8 & 0.8 & 5.9 & 820.4 & 96.2 \\
\hline Bronco & - & - & 5.7 & 840.3 & 69.9 & 5.8 & 930.1 & 2.2 & 5.8 & 781.9 & 76.8 \\
\hline Cannery Row & 6.3 & 1045.0 & - & - & - & - & - & - & - & - & - \\
\hline Glacier & 4.8 & 820.9 & - & - & - & - & - & - & - & - & - \\
\hline Premiere & - & - & 5.6 & 827.2 & 94.7 & 5.9 & 958.9 & 2.4 & 5.8 & 625.8 & 60.6 \\
\hline Sharp Shooter & - & - & 5.9 & 947.7 & 93.5 & 5.6 & 1023.6 & 0.9 & 5.9 & 821.0 & 95.0 \\
\hline Sniper & 5.3 & 902.0 & - & - & - & - & - & - & - & - & - \\
\hline Salinas & 7.5 & 700.1 & 8.0 & 782.9 & 95.8 & 8.0 & 781.5 & 1.0 & 8.0 & 676.2 & 87.5 \\
\hline Silverado & - & - & 8.0 & 695.0 & 92.2 & - & - & - & - & - & - \\
\hline $\mathrm{LSD}_{0.05}{ }^{\mathrm{w}}$ & 1.2 & 166.1 & 0.4 & 89.2 & 14.9 & 0.5 & 143.2 & 2.3 & 0.5 & 88.5 & - \\
\hline
\end{tabular}

${ }^{\mathrm{z}}$ Corky root ratings using Brown and Michelmore's (1988) scale of 0-9.

'Number of leaves with tipburn per head.

${ }^{x}$ Statistical analysis could not be performed because some plots were not harvested by shippers.

weast significant differences at $P<0.05$.

resistance genes (Grube and Ochoa, 2005) and were not resistant to lettuce drop (Sclerotinia minor Jagger). Other disease reactions have not been tested.

Performance and adaptation. In the field trials mentioned, six plants were randomly sampled from each plot. Frame and wrapper leaves were removed and the heads were harvested and weighed. The heads were then cut open to measure head diameter, head height, core length, and core diameter at the base. The number of leaves with tipburn disorder in each head was also recorded. The remaining plants in the plots of growers' fields were divided into harvestable and nonharvestable categories and harvested by commercial shippers. The percentage of plants in the harvestable category that were actually harvested was noted as harvest \% (Ryder, 1986).

In general, the head weight of the breeding lines was significantly higher than 'Salinas' that was released in 1975 but comparable to the newer commercial cultivars (Table 1). Harvest percentage, another measure of yield, of the breeding lines also compared favorably to commercial cultivars. The environmental conditions at Spence Farm in 2005 seemed to favor the development of tipburn, whereas there was only

Table 2. Mean values of head characteristics of lettuce breeding lines and cultivars evaluated in four trials in Salinas Valley of California during 2004 and 2005 growing seasons.

\begin{tabular}{lcccc}
\hline Genotype & Head diam $(\mathrm{cm})$ & Head ht $(\mathrm{cm})$ & Core length $(\mathrm{cm})$ & Core diam $(\mathrm{cm})$ \\
\hline $04-0344$ & 16.4 & 14.7 & 6.8 & 3.8 \\
$04-0350$ & 16.6 & 15.9 & 7.7 & 3.4 \\
$04-0353$ & 16.6 & 15.6 & 7.0 & 3.4 \\
$04-0363$ & 17.1 & 15.9 & 7.1 & 3.4 \\
$04-0368$ & 16.5 & 16.2 & 5.9 & 3.3 \\
$04-0375$ & 16.4 & 16.0 & 7.0 & 3.4 \\
$04-0379$ & 16.7 & 15.9 & 5.9 & 3.3 \\
Bronco & 16.8 & 16.5 & 6.9 & 3.6 \\
Premiere & 15.1 & 15.1 & 6.2 & 3.8 \\
Sharp Shooter & 16.6 & 15.9 & 6.9 & 3.8 \\
Salinas & 15.4 & 15.0 & 5.0 & 0.1 \\
LSD $_{0.05}{ }^{2}$ & 0.5 & 0.4 & 0.5 &
\end{tabular}

${ }^{\mathrm{z}}$ Least significant differences at $P<0.05$.

negligible tipburn observed in the other three trials. Therefore, only tipburn results from the 2005 Spence Farm trial are presented in Table 1. Although no significant differences were detected among the genotypes tested, the breeding lines seemed to have tipburn reactions similar to 'Salinas', a cultivar with a high level of tolerance to tipburn.

The head diameter and head height of the breeding lines were significantly larger than 'Premiere' and 'Salinas' but were similar to 'Bronco' and 'Sharp Shooter' (Table 2). A relatively short core length is generally preferred by most lettuce processors. The breeding lines each had core length comparable to commercial cultivars with the exception of 04-0350.

In the limited trials, the breeding lines performed well in the Salinas Valley, producing a high percentage of heads of adequate size, shape, and uniformity. The adaptation of these breeding lines to other lettuce-growing regions has not been evaluated.

\section{Seed Availability}

Limited samples of seed are available from the authors for distribution to all interested parties for research purposes, including the development and commercialization of new cultivars. Samples will also be deposited in the National Plant Germplasm System. It is requested that appropriate recognition be made if the breeding lines contribute to research or the development of new germplasm, breeding lines, or cultivars.

\section{Literature Cited}

Brown, P.R. and R.W. Michelmore. 1988. The genetics of corky root resistance in lettuce. Phytopathol. 78:1145-1150.

Dinant, S. and H. Lot. 1992. Lettuce mosaic virus: A review. Plant Pathol. 41:528-542.

Grube, R.C. and O.E. Ochoa. 2005. Comparative genetic analysis of field resistance to downy mildew in the lettuce cultivars 'Grand Rapids' and 'Iceberg'. Euphytica 142:205-215.

Nicaise, V., S. German-Retana, R. Sanjuan, M.-P. Dubrana, M. Mazier, B. Maisonneuve, T. Candresse, C. Caranta, and O. LeGall. 2003. The eukaryotic translation initiation factor $4 \mathrm{E}$ controls lettuce susceptibility to the potyvirus lettuce mosaic virus. Plant Physiol. 132:12721282.

O’Brien, R.D. and A.H.C. van Bruggen. 1990. Soil fumigation with dazomet and methyl bromide for control of corky root of iceberg lettuce. Plant Dis. 74:1022-1025.

Patterson, C.L., R.G. Grogan, and R.N. Campbell. 1986. Economically important diseases of lettuce. Plant Dis. 70:982-987.

Ryder, E.J. 1970. Inheritance of resistance to common lettuce mosaic. J. Amer. Soc. Hort. Sci. 95:378-379.

Ryder, E.J. 1986. Lettuce breeding, p. 433-474. In: M.J. Bassett (ed.). Breeding vegetable crops. AVI Publishing, Westport, Conn.

Ryder, E.J. 1991. 'Salinas 88' lettuce. HortScience 26:439-440.

Ryder, E.J. 2002. A mild systemic reaction to lettuce mosaic virus in lettuce: Inheritance and interaction with an allele for resistance. J. Amer. Hort. Sci. 127:814-818.

Ryder, E.J. and W. Waycott. 1994. Crisphead lettuce resistant to corky root: Cultivars Glacier and Misty Day and 16 resistant breeding lines. HortScience 29:335-336.

Sarreal, P.M. 1997. Multiple disease resistance in lettuce. U.S. Patent No. 5,684,226. 17 Jan. 
2007. http://patft.uspto.gov/netacgi/nph-Parser? Sect $1=$ PTO $1 \&$ Sect $2=$ HITOFF $\& d=$ PALL $\& \mathrm{p}=1 \& \mathrm{u}=\% 2$ Fnetahtml $\% 2 \mathrm{FPTO} \% 2 \mathrm{Fsrchnum} . \mathrm{htm}$ $\& \mathrm{r}=1 \& \mathrm{f}=\mathrm{G} \& \mathrm{l}=50 \& \mathrm{~s} 1=5,684,226 . \mathrm{PN} . \& \mathrm{OS}=\mathrm{P}$ $\mathrm{N} / 5,684,226 \& \mathrm{RS}=\mathrm{PN} / 5,684,226$.

van Bruggen, A.H.C. 1997. Corky root, p. 28 29. In: R.M. Davis, K.V. Subbarao, R.N. Raid, and E.A. Kurtz (eds.). Compendium of lettuce diseases. APS Press, St. Paul, Minn. van Bruggen, A.H.C. and V.E. Rubatzky. 1992. Use of transplants instead of direct seeding to reduce corky root severity and losses due to corky root in iceberg lettuce. Plant Dis. 76:703-708.

Yabuuchi, E., Y. Kosako, T. Naka, S. Suzuki, and I. Yano. 1999. Proposal of Sphingomonas suberifaciens (van Bruggen, Jochimsen, Brown 1990) comb. Nov., sphingomonas natatoria (Sly 1985) cob. Nov., Sphingomonas ursincola (Yurkov et al. 1997) comb. Nov., and emendation of the genus Sphingomonas. Microbiol. Immunol. 43:339-349.

Zerbini, F.M. and R.L. Gilbertson. 1997. Lettuce mosaic, p. 43-44. In: R.M. Davis, K.V. Subbarao, R.N. Raid, and E.A. Kurtz (eds.). Compendium of lettuce diseases. APS Press, St. Paul, Minn 